\title{
An Empirical Study on the Pass-Through Effect of RMB Nominal Effective Exchange Rate on Import Price
}

\author{
Alin Xia \\ Jinan University, Guangzhou, China \\ Email: 624224654@qq.com
}

How to cite this paper: Xia, A.L. (2017) An Empirical Study on the Pass-Through Effect of RMB Nominal Effective Exchange Rate on Import Price. Modern Economy, 8, 181-190.

https://doi.org/10.4236/me.2017.82012

Received: December 21, 2016

Accepted: January 23, 2017

Published: January 26, 2017

Copyright $\odot 2017$ by author and Scientific Research Publishing Inc. This work is licensed under the Creative Commons Attribution International License (CC BY 4.0).

http://creativecommons.org/licenses/by/4.0/

\begin{abstract}
Starting from ERPT model, the paper decomposes RMB nominal effective exchange rate published in BIS into level and volatility, and analyzes the pass-through effects of RMB nominal effective exchange rate into import price from level and volatility under GARCH model. The conclusions are that, the pass-through effect of RMB nominal effective exchange rate to the level of import price is not complete, and the volatility of RMB nominal effective exchange rate has a negative impact on the volatility of import price and also has a time lag. Error correction mechanism shows that it needs about 8 months for import price to return to a balanced level after the changes of exchange rate.
\end{abstract}

Keywords

Exchange Rate Pass-Through, Import Price, Volatility

\section{Introduction}

RMB exchange rate reform began since July 21, 2015, and the Chinese central bank announced to consummate the middle price of RMB against US dollars in August 11, 2015, so RMB had fallen by $5 \%$ in a month, which was the largest monthly decline in nearly 20 years. After China's RMB accession to the SDR, the fluctuation of exchange rate will be greatly improved. While the volatility of exchange rate has become an important part of the economic life, whether the increasing volatility of exchange rate would affect the domestic price level and intervene in the monetary policy or not, has become a hot issue for scholars in recent years.

Under the floating exchange rate system, the volatility of exchange rate will seriously affect the balance of international payments and the economic benefits 
of foreign trade enterprise. The change of exchange rate has impacts on domestic inflation and economic situation through different ways. Firstly it directly affects import price, which is the first stage of pass-through of exchange rate to price, then has indirect effects on other prices. For example, exchange rate changes make the price of imported raw materials changes, which lead to changes in the production cost of domestic manufacturers, and ultimately affect the producer price index, consumer price index, etc.

The traditional theory of exchange rate is based on purchasing power parity, so in the law of one price, the exchange rate transmission is complete. In practice, however, the exchange rate pass-through effect is not constant, but changes with time. In 1990s, many countries had experienced currency devaluation, but the economy of many industrialized countries did not seem to response, which prompted people to study on the stability of the pass-through effect of exchange rate to the price and the reasons why exchange rate pass-through effect declined universally and persistently [1] [2] [3]. As far as monetary policy is concerned, low exchange rate pass-through effect indicates that exchange rate fluctuations may lead to a lower expenditure-switching effect of domestic monetary policy. As a consequence, monetary policy effectiveness is greater for adjusting the domestic economy, and the independence of macro-economic regulation is easy to achieve, and it is more conducive to control inflation. On the contrary, high exchange rate pass through effect means that the autonomy of monetary policy is low. Therefore, a comprehensive study of the impact of exchange rate on the domestic economy and pass-through effect of exchange rate to the import price is essential.

The rest of the paper is organized as follows: Section 2 provides a summary of the recent literature; Section 3 builds the framework of the model; Section 4 discusses the empirical strategy; Section 5 concludes.

\section{Review of the Literature}

The discussion on the reasons of incomplete exchange rate pass-through tended to analyze the micro factors in the early period. Krugman [4] proposed "pricing to market". Hooper and Mann [5] studied the impacts of makeups on the exchange rate pass-through. Other micro factors such as incomplete product substitution [6], price stickiness and valuation currency [7] [8], also affected exchange rate pass-through. After 1990s, some scholars from the macro perspective discussed incomplete exchange rate pass-through. Taylor [9] suggested that the low inflation environment was the cause of the decline in exchange rate pass through effect. Empirical studies on the level of industrialization from the perspective of industrialization of Gagnon and Ihrig [10], Choudri and Hakura [11] and Frankel, David and Shang-Jin Wei [12] confirmed the conclusion of Taylor (2000). Based on the verification of Taylor (2000), Campa and Goldberg [13] also showed that changes of the structure of domestic imports were also an impact factor on the exchange rate pass-through.

The domestic research on exchange rate pass-through effect began from 2000. 
Based on the existing model of foreign theoretical and empirical model, a large number of researches pointed out the incomplete exchange rate pass-through and RMB exchange rate pass through effect coefficient is small. Bu Yongxiang [14] discussed the pass-through effect of RMB exchange rate to the domestic price level, and got the conclusion that the producer price is affected more than the retail price index. Bi Yujiang [15] suggested, compared to the consumer price index and producer price index, the impact of exchange rate fluctuations on the import prices is the weakest, the reason of which may be the existence of a large number of intermediate goods in the process of import. Based on the cost plus model, Xu Wei and Fu Xiongguang [16] showed that the domestic inflation environment and the import structure may be the factors that influence RMB nominal effective exchange rate pass-through to the import price. Huang Manying and Gao Zhicun [17] studied the effects of RMB exchange rate levels and volatility on prices of China's exports to US under HS Classification.

The empirical research methods often used in the study of the RMB exchange rate pass-through are OLS regression, co-integration and error correction model, VAR model and panel data of two stage instrumental variable method and rolling regression method etc. These can be seen in Bu Yongxiang (2001), Bi Yujiang (2008), Shi Jianhuai and Fu Xiongguang and Xu Wei [18], Wang Jinbin and Li Nan [19], Cao Wei and Shen Yu [20].

Up to now, though there are a large number of researches on the RMB exchange rate pass-through effects, most studies [16] [20] [21] [22] [23] have not considered the level and volatility of exchange rate pass-through effects to import price. Compared with the previous researches, the innovation of this paper lies in research methods; the prominent characteristics of which are decomposing the nominal effective exchange rate of RMB into average level and volatility, and nesting GARCH model and error correction model to investigate the RMB nominal effective exchange rate pass-through effect to import prices.

\section{Theoretical Framework}

The micro-foundations of pricing behavior by exporters are a useful starting point for understanding the dynamics of exchange rate pass through to import prices. The import price for any country $j, p^{m}$ is a transformation of the export price of that country's trading partners $p^{x}$, using the exchange rate (domestic currency per unit foreign currency) $E$ :

$$
p^{m}=E \times p^{x}
$$

Using lowercase letters to reflect logarithms, we get:

$$
p^{m}=e+p^{x}
$$

The export prices are a markup $\left(m_{k u p^{x}}\right)$ over exporter marginal costs, that is:

$$
p^{x}=m c^{x}+m k u p^{x}
$$

we rewrite Equation (2):

$$
p^{m}=e+m c^{x}+m k u p^{x}
$$


Exporter marginal costs $m c^{x}$ are rising with export market wages $w^{x}$, and import country's market demand conditions $y^{m}$ :

$$
m c^{x}=c_{1} y^{m}+c_{2} w^{x}
$$

Then we allow markups to have both an industry specific fixed effect and a component that is sensitive to macroeconomic conditions, expressed at this point as a function only of the exchange rates for simplicity,

$$
\text { mkup }^{x}=\alpha+\Omega e
$$

So that import prices are written in general form as follows:

$$
p^{m}=\alpha+(1+\Omega) e+c_{1} y^{m}+c_{2} w^{x}
$$

The exchange rate pass-through, defined as the partial elasticity of import price with respect to exchange rate, is $\beta=1+\Omega$. The Equation (7) provides the relationship between import price and exchange rate, the cost of exporters and other control variables (such as domestic GDP and domestic price competition).

We present the arguments of the import price Equation (7) through a log linear regression specification similar to that tested throughout the ERPT literature, namely

$$
p_{t}=\alpha+\beta e_{t}+\delta w_{t}+\varphi y_{t}+\varepsilon_{t}
$$

\section{Empirical Strategy}

\subsection{Method}

GARCH model [24] is widely used in the single variable time series variance. Compared with the ordinary regression model, GARCH model provides the variance of error for further modeling, especially suitable for the analysis of volatility. Based on the nominal effective exchange rate of RMB decomposed into average level (neer) and volatility (var neer), the exchange rate volatility is considered as the explanatory variables of the variance equation of GARCH model. We employ GARCH model to focus on the impacts of exchange rate volatility on import price volatility. At the same time, stable and long-term relationships between import prices, nominal effective exchange rate, domestic producer price and foreign production cost are determined; we combine the error correction model (ECM) to study the short-term dynamic relationship between variables. The model established in this paper is:

$$
\left\{\begin{aligned}
\Delta i m p_{t}= & \pi_{0 i}+\sum_{i=1} \pi_{1 i} \Delta i m p_{t-i}+\sum_{i=1} \pi_{2 i} \Delta \text { neer }_{t-i}+\sum_{i=1} \pi_{3 i} \Delta p p i_{t-i}+\sum_{i=1} \pi_{4 i} \Delta w c p i_{t-i} \\
& +\sum_{i=1} \pi_{5 i} g d p_{t-i}+e c m_{t-i}+\varepsilon_{t} \\
\sigma_{t}^{2}=\omega & \alpha \varepsilon_{t-1}^{2}+\beta \sigma_{t-1}^{2}+\varphi \sum_{j=1} \text { var neer } t_{t-j}
\end{aligned}\right.
$$

\subsection{Data Description}

There are seven categories of indicator data in this paper. We use a monthly data set for the period January 1993-December 2015 consisting of 264 observations, 
and all data are converted to base year 2010. More precisely, our empirical analysis uses import prices (imp) obtained from the WIND rather than unit value indices, because import price index measures actual transaction prices of imported goods, and the unit value indices may change just due to a change in quantity without any change in price.

The International Monetary Fund (IMF) and the bank for International Settlements (BIS) have announced the effective exchange rate of RMB, but Yin Fusheng, Xia Alin and MoYang [25] suggested that BIS data is more in accordance with the Chinese economy realities, so the nominal effective exchange rate index (neer) provided by BIS is used in the research.

Since there is no direct use of foreign manufacturers cost data series, according to the previous research literature (Pollard and Coughlin, 2003), we regard the world consumer price index ( $w c p i)$ from the IMF (IFS).as a proxy for production of foreign manufacturers cost. Domestic Producer's Price for Manufactured Products $(p p i)$ is used to describe the competitive situation of imported products in China, and the data is from the National Bureau of Statistics of China. It's impossible to get monthly GDP data, but we construct a proxy by taking advantage of China Economic Net's reporting of industrial value added, which is similar to previous literature. Finally, we apply GARCH $(1,1)$ model to get conditional variance of nominal effective exchange rate (var neer).

\subsection{Unit Roots and Cointegration Tests}

We have ADF tests on these seven time series by a seasonally adjusted, and the unit root test results show that, Varneer is stationary at the $1 \%$ significance, while the other six time series are non-stationary at the $5 \%$ significance. Thus we take the first difference of these six variables, and eliminate non-stationary features (Table 1).

Table 1. Unit root test results after seasonal adjustment.

\begin{tabular}{cccc}
\hline & & \multicolumn{2}{c}{ Critical values } \\
Variable & ADF test statistic & $1 \%$ & $5 \%$ \\
\cline { 3 - 4 }$i m p$ & -2.685181 & -3.9969 & -3.4287 \\
$\Delta i m p$ & -7.129538 & -3.9974 & -3.4290 \\
neer & -2.004260 & -3.9971 & -3.4288 \\
$\Delta$ neer & -11.227270 & -3.9971 & -3.4288 \\
$p p i$ & -2.380421 & -3.9971 & -3.4288 \\
$\Delta p p i$ & -6.414848 & -3.9971 & -3.4288 \\
$g d p$ & 0.705691 & -3.9973 & -3.4289 \\
$\Delta g d p$ & -14.966260 & -3.9973 & -3.4289 \\
$w c p i$ & -3.226988 & -3.9971 & -3.4288 \\
$\Delta w c p i$ & -7.917159 & -3.9971 & -3.4288 \\
var neer & -7.735825 & -3.4579 & -2.8735 \\
\hline
\end{tabular}


We test for the cointegrating relationship between imp, neer, ppi, wcpi and $g d p$ using the procedures of Johansen test. The results present a cointegrating relationship between imp, neer, ppi and wcpi.

$$
\text { imp }=-0.5706 \times \text { neer }+0.03698 p p i+1.4020 \times w c p i
$$

According to cointegration equation, in the long run, the import price and the RMB nominal effective exchange rate are negatively correlated. AS RMB nominal effective exchange rate appreciate by $1 \%$, import price index fall by $0.57 \%$, which means the exchange rate pass through into import prices is incomplete. Domestic producer prices and import prices showed a positive relationship and long-term change in trend test results show that, as domestic producer prices rise $1 \%$, China's import prices rise $0.037 \%$. This may be because intermediate inputs that have a low degree of domestic substitution account for a large proportion in China's commodity structure of imports. Therefore, when domestic production change growth, demand for imports also increased, thus improving the level of import prices. China's import price is mostly influenced by the foreign production cost, and its influence is more than the exchange rate.

\subsection{GARCH Estimation}

Long-term stable relationship between import prices, nominal effective exchange rate, domestic producer price and foreign production cost is determined. We combine the error correction model (ECM) to study the short-term dynamic relationship between variables. OLS is used to estimate the conditional mean value equation, and the conditional variance is tested by LM ARCH. The results show the residual sequence of the model has an ARCH effect. Since the model introduces the error correction mechanism, we have to choose each variable lag order to estimate parameter, so we refer to the general to specific method of and Hendry [26], and gradually eliminate the lag period of the variable, to obtain a concise form of model. Estimated results are reported as follows (Table 2).

Firstly, the impact of RMB nominal effective exchange rate volatility on import prices is delayed, that is to say, if the RMB nominal effective exchange rate volatility increased by $1 \%$, the import price volatility will decline by 2.01 percentage points 3 months later. After adding the proxy variables ( $g d p$ ) that represent the domestic aggregate demand (model 2), the volatility of the nominal effective exchange rate has a significant effect on the volatility of the import price, and the short-term pass-through effect coefficient increases by 0.57 compared with model 1.

Secondly, Excluding foreign domestic producer price and production cost of two variables (model 3 and model 4), the nominal effective exchange rate passthrough into the import prices becomes significant. This may be due to the collinearity between the nominal effective exchange rate and the foreign production costs or other variables.

Thirdly, Error correction term is negative and statistically significant at the $1 \%$ level, which shows the process of RMB nominal effective exchange rate pass-through to import prices has dynamic self-correcting mechanisms by 
Table 2. Empirical results.

\begin{tabular}{|c|c|c|c|c|c|}
\hline & Variable & Model 1 & Model 2 & Model 3 & Model 4 \\
\hline \multirow{12}{*}{$\begin{array}{c}\text { Mean } \\
\text { equation }\end{array}$} & neer $(-3)$ & -0.0216 & -0.0866 & $-0.1431^{\star *}$ & $-0.1641^{\star *}$ \\
\hline & & $(-0.3003)$ & $(-1.1098)$ & $(-1.9860)$ & $(-2.2905)$ \\
\hline & ppi & $0.5130^{* *}$ & $0.7125^{\star}$ & - & - \\
\hline & & $(2.3860)$ & $(3.7798)$ & - & - \\
\hline & $w c p i$ & $2.6616^{*}$ & $3.0909^{*}$ & - & - \\
\hline & & $(4.0999)$ & $(4.7669)$ & - & - \\
\hline & $g d p$ & - & $-0.0052^{*}$ & - & $-0.0029^{* * *}$ \\
\hline & & - & $(-3.9584)$ & - & $(-1.6730)$ \\
\hline & ecm $(-1)$ & $-0.1330^{*}$ & $-0.1468^{*}$ & $-0.1255^{*}$ & $-0.1173^{*}$ \\
\hline & & $(-5.7817)$ & $(-5.9502)$ & $(-5.3140)$ & $(-4.8427)$ \\
\hline & constant & 1.4216 & 1.4549 & 2.116 & 2.032 \\
\hline & & $(4.2759)$ & $(4.3389)$ & $(6.3938)$ & $(5.9817)$ \\
\hline \multirow{8}{*}{$\begin{array}{l}\text { Variance } \\
\text { equation }\end{array}$} & $\operatorname{RESID}(-1)^{\wedge} 2$ & $0.3553^{\star}$ & $0.2532^{*}$ & $0.4056^{*}$ & $0.4144^{*}$ \\
\hline & & $(3.1473)$ & $(3.8677)$ & $(3.4670)$ & $(3.0893)$ \\
\hline & $\operatorname{GARCH}(-1)$ & $0.4311^{*}$ & $0.4133^{\star}$ & $0.4755^{\star}$ & $0.4316^{*}$ \\
\hline & & $(3.2533)$ & $(3.7182)$ & $(4.1617)$ & $(3.3254)$ \\
\hline & var neer & - & - & $-0.1881^{* * *}$ & $-0.2027^{* * *}$ \\
\hline & & - & - & $(-1.7393)$ & $(-1.7108)$ \\
\hline & var neer $(-3)$ & $-0.2012^{*}$ & $-0.2583^{\star}$ & - & - \\
\hline & & $(-3.7842)$ & $(-7.6104)$ & - & - \\
\hline \multicolumn{2}{|c|}{ Adjusted R-squared } & 0.2535 & 0.2848 & 0.1050 & 0.1133 \\
\hline \multicolumn{2}{|c|}{ Durbin-Waston Statistic } & 2.3246 & 2.3587 & 2.0348 & 2.0394 \\
\hline
\end{tabular}

Note: ${ }^{*}{ }^{* *},{ }^{* * *}$ respectively indicates significant at $1 \%, 5 \%, 10 \%$ level.

short-term volatility adjustment to long-run equilibrium. Error correction coefficient is 0.133 , namely, once deviating from the equilibrium level, import prices will be back to a balanced level of $13.3 \%$ within a month, and return to the equilibrium level completely within 8 months.

Fourthly, the ARCH effect test is carried out again; we remark the square of the residual series has no self-correlation. The sum of ARCH and GARCH coefficients in the model is 0.6665 , which indicates conditional variance has strong volatility persistence, and outside information on the impact of exchange rate cannot fully pass to the import price in the short term, which is a gradual process of digestion.

Finally, the above results both indicate, the hypothesis that RMB nominal effective exchange rate pass-through to import prices is equal to zero is rejected. It means foreign exporters will not completely price in the currency of the import 
country. The hypothesis that RMB nominal effective exchange rate pass-through to import prices is complete is also rejected, which shows foreign exporters will not completely apply the method of producer currency pricing, and not transfer the shock of exchange rate to produce prices. The coefficient of the foreign manufacturer's production cost, wcpi, is significantly higher than that of the exchange rate volatility, which shows that the influence of the foreign manufacturer's cost on the import price is stronger than that of the exchange rate.

\section{Concluding Remarks}

Starting from the ERPT empirical model employed in the most of the literature, by using error correction mechanism and the GARCH model to examine pass-through effects of RMB nominal effective exchange rate into import prices, especially the impact on import price volatility. The results show that the effect of RMB nominal effective exchange rate on import price volatility is delayed appeared in 3 months later. Impact of information on exchange rate pass to import prices requires a certain period of absorption. The error correction model indicates the pass-through effect of the nominal effective exchange rate to the import prices has a mechanism from short-term fluctuation to long-term equilibrium. Based on the empirical results; this paper draws the following revelation:

Expand the range of RMB exchange rate volatility appropriately and increase the flexibility of the RMB exchange rate. The impact of exchange rate on the volatility of import prices is delayed, and the elasticity is about $20 \%$, which indicates the pass-through effects are low. Namely, the influence of import pricespassing to the domestic price is more limited, so exchange rate volatility in a small scope could promote macroeconomic flexibility. Moreover, after RMB joining SDR, the RMB exchange rate will be more elasticity and flexibility in the case of the general trend of smooth and two-way fluctuations of the RMB exchange rate greatly will become the norm.

It's limited to rely on exchange rate policy to adjust the balance of international payments. The role of devaluation or appreciation of RMB playing in adjusting import and export will not achieve desired effect. Therefore, we cannot take the exchange rate as the starting point, but combined with industrial policy, import and export situation, as well as with the cooperation policy of trading partners, etc. to adjust the balance of payment.

As is Known, GARCH analysis is extended to include asymmetries. Maybe it can provide a fertile ground to study ERPT phenomenon, which is left for future research.

\section{References}

[1] Bouakez, H. and Rebei, N. (2008) Has Exchange Rate Pass-through Really Declined? Evidence from Canada. Journal of International Economics, 2, 249-267. https://doi.org/10.1016/j.jinteco.2007.12.004

[2] Bussiére, M.andChiaie, S.D. and Peltonen, T. (2014) Exchange Rate Pass-Through in the Global Economy: The Role of Emerging Market Economies. IMF Economic Review, 1, 146-178. https://doi.org/10.1057/imfer.2014.5 
[3] Goldberg, L. and Campa, J. (2010) The Sensitivity of the CPI to Exchange Rates: Distribution Margins, Imported Inputs, and Trade Exposure. The Review of Economics and Statistics, 2, 392-407. https://doi.org/10.1162/rest.2010.11459

[4] Krugman, P. (1986) Pricing to Market when the Exchange Rate Changes. NBER Working Paper No. 1926.

[5] Hooper, P. and Mann, C. (1989) Exchange Rate Pass-Through in the 1980s: The Case of US Imports of Manufactures. Brookings Papers on Economic Activity, No 1.

[6] Yang, J. (1997) Exchange Rate Pass-Through into US Manufacturing Industries. Review of Economics \& Statistics, 1, 95-104. https://doi.org/10.1162/003465397556430

[7] Obstfeld, M. and Rogoff, K. (2002) Global Implications of Self-Oriented National Monetary Rules. Quarterly Journal of Economics, 2, 503-535. https://doi.org/10.1162/003355302753650319

[8] Betts, C. and Devereux, M.B. (2000) Exchange Rate Dynamics in a Model of Pricing-to-Market. Journal of International Economics, 1, 215-244. https://doi.org/10.1016/S0022-1996(98)00036-1

[9] Taylor, J.B. (2000) Low Inflation, Pass-Through, and the Pricing Power of Firms. European Economic Review, 7, 1389-1408. https://doi.org/10.1016/S0014-2921(00)00037-4

[10] Gagnon, J. and Ihrig, J. (2004) Monetary Policy and Exchange Rate Pass-Through. International Journal of Finance \& Economics, 4, 315-338. https://doi.org/10.1002/ijfe.253

[11] Choudri, E. and Hakura, D. (2006) Exchange Rate Pass through to Domestic Prices; Does the Inflationary Environment Matter? Journal of International Money and Finance, 25, 614-639. https://doi.org/10.1016/j.jimonfin.2005.11.009

[12] Jeffrey, F., Parsley, D. and Wei, S.-J. (2005) Slow Pass-Through around the World: A New Import for Developing Countries? NBER Working Paper No. 11199.

[13] Campa, J. and Goldberg, L. (2005) Exchange Rate Pass-Through into Import Prices. The Review of Economics and Statistics, 4, 679-690. https://doi.org/10.1162/003465305775098189

[14] Bu, Y.X. (2001) The Impact of RMB Exchange Rate Fluctuation on Domestic Price Level. Journal of Financial Research, 3, 78-88.

[15] Bi, Y.J. (2008) RMB's Exchange Rate Change and Commodity Import Price: An Empirical Analysis Based on VECM. The Journal of Quantitative \& Technical Economics, 8, 70-82.

[16] Xu, W. and Fu, X.G. (2008) Research on the Pass-Through Effect of RMB Nominal Effective Exchange Rate on Import Price. Journal of Financial Research, 9, 77-90.

[17] Huang, M.Y. and Gao, Z.C. (2012) The Effects of RMB Exchange Rate Levels and Volatility on Prices of China's Exports to US. Statistics Research, 2, 10-20.

[18] Shi, J.H. and Fu, X.G. and Xu, W. (2008) Pass-Through of RMB Exchange Rate to Chinese Domestic Prices. Economic Research Journal, 7, 52-64.

[19] Wang, J.B. and Li N. (2009) Exchange Rate Pass-Through: The Case of China. Economic Research Journal, 4, 17-27.

[20] Cao, W. and Shen, Y. (2013) Research on RMB Exchange Rate Pass-Through, Industrial Import Prices and Inflation: 1966-2011. Journal of Financial Research, 10, 68-80.

[21] Yang, Y.L. and Yang, F. (2016) The Threshold Pass-Through Effect of RMB Ex- 
change Rate and Expectations on Import Price: Analysis Based on the Variability of Marginal Costs. Word Economy Studies, 10, 62-75.

[22] Kilic, R. (2016) Regime-Dependent Exchange-Rate Pass-Through to Import Prices. International Review of Economics and Finance, 41, 295-308. https://doi.org/10.1016/j.iref.2015.08.003

[23] Cheikh, N.B. and Rault, C. (2016) Recent Estimates of Exchange Rate Pass-Through to Import Prices in the Euro Area. Review of World Economies, 1, 1-37.

[24] Bollerslevb, T. (1986) Generalized Autoregressive Conditional Heteroskedasticity. Journal of Econometrics, 3, 307-327. https://doi.org/10.1016/0304-4076(86)90063-1

[25] Yin, F.S., Xia A.L. and Mo, Y. (2016) Research on the Market Segmentation Phenomenon of RMB Nominal Exchange Rate-Empirical Evidence from Structural Break Theory. Industrial Economic Review, 3, 153-160.

[26] Hendry, D.F. (1995) Dynamic Econometrics. Oxford University, Oxford. https://doi.org/10.1093/0198283164.001.0001

Submit or recommend next manuscript to SCIRP and we will provide best service for you:

Accepting pre-submission inquiries through Email, Facebook, LinkedIn, Twitter, etc. A wide selection of journals (inclusive of 9 subjects, more than 200 journals)

Providing 24-hour high-quality service

User-friendly online submission system

Fair and swift peer-review system

Efficient typesetting and proofreading procedure

Display of the result of downloads and visits, as well as the number of cited articles

Maximum dissemination of your research work

Submit your manuscript at: http://papersubmission.scirp.org/

Or contact me@scirp.org 